\title{
LARANGAN PEREDARAN MINUMAN KERAS DALAM PERATURAN DAERAH KABUPATEN GRESIK NOMOR 15 TAHUN 2002 PERSPEKTIF PEMIKIRAN SYAFI'IYAH
}

\author{
Dhofirul Yahya \\ Universitas Maarif Hasyim Latif (UMAHA) Sidoarjo \\ Email: virdho_elgres@yahoo.co.id
}

\begin{abstract}
Research objectives: 1) to analyze the concept of the prohibition of liquor distribution in the district regulation of Gresik number 15 of 2002 concerning the prohibition of the distribution of liquor. 2) to analyze the prohibition of the distribution of liquor in the regional regulation, including the prohibition of the category of Syafi'iyah's perspective. The research method used is descriptiveanalytical analysis, analyzed using a deductive mindset which begins with the theory of the concept of prohibiting khamar from the perspective of Syafi'iyah's thought and then drawn to the theory then drawn conclusions. The results of this study conclude 1). The concept of prohibiting the distribution of liquor in the Gresik regulation is prohibited, including Prohibition for individuals or legal entities to produce, distribute, trade, offer, hoard, store, mix, entertain, carry and/or drink liquor. The prohibition here applies to all regions of Gresik regency which includes all residents of Gresik district and all residents of other regions and/or other people in the district of Gresik. 2) Prohibition of the distribution of liquor in the Gresik regional regulation in general, including the prohibition of alcoholic categories in Syafi'iyah's perspective
\end{abstract}

Keywords: Prohibition of Regional Regulation No. 15 of 2002, Syafi'iyah Thought

\begin{abstract}
Abstrak
Tujuan penelitian: 1) untuk menganalisis konsep larangan peredaran minuman kerasdalam peraturan daerah kabupaten Gresik nomor 15 tahun 2002 tentang larangan peredaran minuman keras. 2) untuk menganalisis larangan peredaran minuman keras dalam peraturan daerah itu termasuk kategori larangan khamar perspektif pemikiran Syafi'iyah. Metode penelitian yang digunakan deskripstifanalitis, dianalisis dengan menggunakan pola pikir deduktif yang diawali dengan mengemukakan teori konsep larangan khamar perspektif pemikiran Syafi'iyah kemudian di tarik ke teori kemudian ditarik kesimpulan. Hasil penelitian ini menyimpulkan : 1). Konsep larangan peredaran minuman keras dalam perda Gresik terdapat larangan, diantaranya: Larangan bagi perorangan atau badan hukum memproduksi, mengedarkan, memperdagangkan, menawarkan, menimbun, menyimpan, mengoplos, menjamu, membawa dan/atau meminum minuman keras. Larangan disini berlaku untuk seluruh daerah kabupaten Gresik yang mencakup seтиa warga mayarakat kabupaten Gresik dan semua warga masyarakat daerah lain dan/atau orang lain yang berada di kabupaten Gresik. 2) Larangan peredaran minuman keras dalam perda Gresik secara umum termasuk kategori larangan khamar perspektif pemikiran Syafi'iyah.

Kata Kunci: Larangan Perda Gresik nomor 15 Tahun 2002, Pemikiran Syafi'iyah
\end{abstract}




\section{A. Pendahuluan}

Gresik merupakan kabupaten yang terkenal dengan sebutan kota wali dan kota santri. Dikatakan kota wali karena di Gresik ada makan sunan Maulana Malik Ibrahim dan Sunan Giri serta makam wali-wali lainnya selain wali songo. Gresik juga disebut kota santri karena di Gresik banyak pondok pesantren disamping juga budaya yang melekat pada masyarakat Gresik adalah kebanyakan budaya santri.

Berangkat dari sebutan Gresik kota wali dan kota santri tersebut, Peran Ulama sangatlah penting sekali dalam membentengi masyarakat Gresik dari kemaksiatan khususnya dalam hal minum-minuman keras. Sebagai langkah pencegahan atas kemaksiatan dalam melaksanakan tugas mencegah kemungkaran, Ulama hanya bisa berdakwah dari masjid ke masjid, dari mushalla ke mushalla dan juga dari mimbar satu ke mimbar pengajian lainnya. Tentunya tidak akan efektif dakwah mencegah kemungkaran ini tanpa adanya dukungan dari pihak lain dalam hal ini adalah pemerintah.

Langkah konkrit Pemerintah untuk ikut andil dalam peran mencegah kemungkaran untuk mewujudkan kota Gresik bersih dari minum-minuman keras adalah dengan mencegah penggunaan minuman keras yang dapat menimbulkan gangguan kesehatan, gangguan ketertiban serta mengganggu keamanan umum dan juga untuk melindungi masyarakat, terutama generasi muda terhadap bahaya penggunaan minuman keras, diperlukan adanya larangan peredaran minuman keras didaerah Kabupaten Gresik atau yang masuk dari wilayah lain. Untuk dapat melaksanakan larangan berbuat kemungkaran sebagaimana yang diharapkan tersebut, maka perlu adanya peraturan daerah yang mengatur tentang larangan peredaran minuman keras sebagai pedoman pemerintah daerah dalam pelarangan peredaran minuman keras, sehingga pemerintah menerbitkan peraturan daerah kabupaten Gresik nomor 15 tahun 2002 tentang larangan peredaran minuman keras,yang disebutkan didalam Pasal 2 : Dilarang bagi perorangan atau badan hukum memproduksi, mengedarkan, memperdagangkan, menawarkan, menimbun, menyimpan, mengoplos, menjamu, membawa dan/atau meminum minuman keras (Peraturan daerah kabupaten Gresik nomor 15 tahun 2002). 
Terbitnya Peraturan daerah kabupaten Gresik nomor 15 tahun 2002 ini, yang oleh sebagian masyarakat disebut dengan Perda Syariahmerupakan wujud langkah konkrit pemerintah dalam pemberantasan minuman keras di kabupaten Gresik sekaligus sebagai pedoman yang dijadikan pegangan dalam pelarangan peredaran minuman keras. Dengan peraturan daerah kabupaten Gresik tentang larangan peredaran minuman keras ini juga, akan memperkokoh hubungan kerja sama antara Kyai dalam posisinya sebagai Ulama dan pemerintah dalam posisinya sebagai Umara' yang saling bersinergi dalam memberantas minuman keras dari kabupaten Gresik, sehingga diharapkan menjadi kabupaten Gresik yang bersih dari peredaran minuman keras.

Adanya peraturan daerah kabupaten Gresik tentang larangan peredaran minuman keras, memunculkan asumsi dari penulis, adakah pemahaman tentang minuman keras, bentuk larangan dan hukuman bagi pelanggarnya, sesuai dengan khamar yang ada dalam hukum Islam. Bertolak dari Asumsi diatas, maka penulis tertarik untuk melakukan penelitian dengan mengkajinya dalam judul "Larangan peredaran minuman keras dalam peraturan daerah kabupaten Gresik nomor 15 tahun 2002 Perspektif Pemikiran Syafi'iyah.

\section{B. Landasan Teori}

1. Khamar adalah sumber yang memabukkan, adapun minuman memabukkan selain khamar mengikuti khamar dalam hukumnya, khamar pada asalnya adalah perasan anggur ketika jadi memabukkan karena adanya tekanan yang kuat dalam perasan tersebut (al-Nawawy. 2010:446). Hakikat Khamar menurut Kebanyakan Syafi'iyah adalah minuman yang memabukkan dari perasan anggur. adapun minuman lain yang memabukkan adalah di qiyaskan pada perasan anggur tersebut (Abdul Hamīd as-Sharwani. 2009:195). Dari pendapat Syafi'iyah tersebut pengertian khamar menjadi jelas bahwa Syafi'iyah tidak membedakan pengertian khamar dari perasan anggur dan dari perasan dari jenis lainnya selagi keduannya sama illahnya yaitu samasama memabukkan. Dan dari segi hukumannya juga sama yaitu hukuman had bagi peminummnya 40 pukulan.

Dalilnya adalah Hadits yang diriwatkan Ibnu Umar RA. Nabi bersabda : 


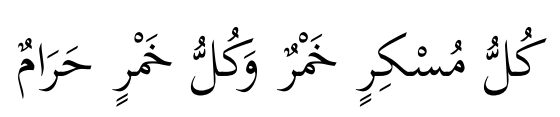

Artinya : Setiap minuman yang memabukkan itu adalah khamar dan setiap khamar haram hukumnya (Abi Dōwud, 1997:5)

Dalam mengomentari hadits diatas al-Nawawi berkata: Dalam hadits tersebut telah jelas bahwa semua minuman yang memabukkan adalah haram hukumnya dan semuanya dinamakan khamar. (al-Nawali, 2010:448).

2. Pengertian Hudud berasal dari kata had, yang menurut bahasa bermakna al man'u (larangan), Adapun had menurut Syara' adalah melarang seseorang yang terkena hukum had untuk kembali melakukan perbuatan yang telah dilakukannya (Ibrahim as-Sayraji, 1994: 373). Dari definisi tersebut menjadi jelas bahwa tujuan dari adanya hukuman had bagi orang yang meminum khamar adalah untuk menjerahkan peminumnya agar tidak mengulangi lagi atas apa yang telah dilakukannya karena perbuatan tersebut tercela dan melanggar batas-batas yang telah diharamkan oleh Allah SWT. Menurut Ali Ajurjan̄̄ dalam kitabnya al-Ta'rifōh " Hudud ialah jama' dari kata Had menurut bahasa bermakna al man'u (larangan) dan menurut syara' adalah hukuman wajib yang telah ditentukan ukurannya atas hak Allah (Ali b. Muhammad Ajurjanī: 2003:68). Dari definisi yang di kemukakan oleh Ajurjanī disini tidak jauh beda dengan definisi sebelumnya yang tujuannya sama yaitu untuk mencegah orang yang meminum minuman keras (khamar) agar berhenti dari perbuatan tercela tersebut dan tidak mengulangi lagi karena minuman keras adalah pangkal kejelekan, walaupun ada kemanfa'atannya tetapi madlaratnya lebih banyak dari pada manfaatnya. Dari definisi ini juga telah jelas dan tegas bahwa hukuman bagi peminum minuman keras atau khamar (berupa had) telah di tentukan ukurannya oleh Allah SWT yaitu 40 dera (pukulan).

3. Hukum bagi peminum minuman keras menurut Syafi'iyah adalah empat puluh pukulan cambuk bagi orang merdeka dan dua puluh cambukan bagi seorang budak. Diperbolehkan bagi seorang Imam menjadikan cambukan menjadi delapan puluh pukulan atas orang merdeka dan empat puluh atas budak, dan kelebihan dari had tersebut dianggap Ta'zir (Muhammad b. Ahmad As Shatirī, 207:716). Apabila seseorang meminum minuman keras 
yang dapat menyebabkan hilangnya akal maka dia wajib di hukum cambuk atau dera. Begitu juga apabila meminum minuman keras banyak memabukkan maka meminum sedikitpun dari minuman tersebut haram dan wajib baginya hukum had menurut Syafi'iyah. Adapun dalil yang di gunakan oleh Imam Syafi'i atas hukuman dera atau cambuk empat puluh kali adalah sebagaimana yang telah dilakukan oleh Nabi SAW, perbuatan Nabi SAW adalah Hujjah yang tidak boleh di tinggalkan dengan mengikuti melakukan selain seperti Nabi. Sedangkan hukuman cambuk lebih dari empat puluh itu adalah dari Umar bin Khattab RA yaitu berupa ta'zir, jadi boleh bagi Imam melakukan cambuk lebih dari empat puluh sebagaimana yang dilakukan oleh Umar bin Khattab (Muhammad b. Ahmad As Shatirī, 207:717)

4. Perbedaan antara had dan ta'zir di sini adalah tanggungan (dlaman), andaikata orang yang dikenakan hukuman had mati pada waktu had atau setelahnya dengan hukuman empat puluh pukulan atau cambukan, maka bagi seorang imam tidak menanggung atas kematian orang yang terkena hukuman had tersebut. Tetapi apabila orang yang terkena hukuman had tersebut mati kerena tambahan pukulan dari empat puluh derah (pukulan) maka seorang imam wajib menanggung atas kematian orang yang di hukum had tersebut.

5. Definisi ta'zir secara bahasa adalah $a l-T a$ 'dīb yang artinya mendidik atau memberi pelajaran yang asalnya dari kata al-'Azru bermakna al- Man'u (mencegah). Adapun ta'zir menurut istilah syara' ialah hukuman untuk mendidik atas perbuatan dosa yang tidak ada ketentuan hukuman had dan kafarahnya. (al-Syirbini. 15). Setiap perbuatan maksiat yang tidak ada ketentuan hukuman had dan kafarahnya maka hukumannya adalah di ta'zir dengan di penjara atau di pukul dengan telapak tangan atau di jelek-jelekkan dengan ucapan lisan, dan bagi seorang Imam berijtihad atas jenis dan kadar hukuman ta'zir. ( al-Syirbini. 16).

\section{Metode Penelitian}

1. Jenis penelitian

Adapun Jenis penelitian yang penulis gunakan disini adalah jenis penelitian kepustakaan (library reseach), yaitu: penelitian yang berusaha 
untuk mengetahui secara konseptual teori yang ada (Muhammad Nasir. 1985:54). Dalam kaitannya dengan yang penulis angkat, penelitian ini berusaha menelusuri konsep larangan peredaran minuman keras serta implikasinya dalam peraturan daerah kabupaten Gresik nomor 15 tahun 2002 dan tinjauannya dalam larangan khamar perspektif pemikiran Syafi'iyah. Karena itu, penelitian di atas termasuk jenis penelitian normatif kualitatif, yang mengungkapkan paparan secara umum, dimana kemudian diambil benang merah dan diambil suatu norma dasar atas pondasi yang dibangun, dibentuk oleh kata-kata berdasarkan teknik pengumpulan data dan analisisnya yang relevan, bukan berupa angka-angka dan statistik. Jenis penelitian ini sengaja digunakan agar dapat mengakomodir diskripsi yang utuh tentang obyek yang diteliti.

2. Sumber Data

Karena penelitian ini merupakan penelitian kepustakaan (library reseach), maka menggunakan data sekunder, yaitu buku-buku atau tulisantulisan ilmiah hukum yang terkait objek penelitian (Muhammad Nasir. 1985:54). Adapun sumber ini antara lain:

1) Peraturan daerah kabupaten Gresik nomor 15 tahun 2002 tentang larangan peredaran minuman keras

2) Peraturan daerah kabupaten Gresik nomor 19 tahun 2004 tentang perubahan atas Peraturan daerah kabupaten Gresik nomor 15 tahun 2002 tentang larangan peredaran minuman keras.

3) Al-Qur'an

4) Al-Hadits

5) Kitab Ulama Syafi'iyah. seperti: Tuhfah al-Muhtaj karya Ibn Hajar al Haitamī, al Majmu' karangan Zakarīyah Muhyiddin an-Nawawi.

6) Wahbah al-Zuhaily, al-Fiqh al-Islam Wōdillatuh

7) Zakariyah al-Anshary, Ghayah al Wusul, dan lain-lain.

3. Teknik Analisis Data

Analisis data adalah pengelompokan menurut suatu urutan manipulasi serta meningkatkan data sehingga mudah untuk dibaca dengan tujuan membatasi penemuan data hingga menjadi suatu data yang layak pakai dan 
tersusun sistematis (Muhammad Nasir, 419). Tehnik analisis data yang penulis gunakan adalah:

a. Metode Deskriptif Analitis, yaitu menganalisa data, baik data primer maupun sekunder, untuk menentukan isi atau makna aturan hukum yang dijadikan rujukan dalam menyelesaikan permasalahan hukum yang menjadi objek penelitian. Metode ini digunakan untuk menganalisis larangan peredaran minuman keras dalam peraturan daerah kabupaten Gresik Nomor 15 Tahun 2002 dan larangan khamar perspektif pemikiran Syafi'iyah.

b. Metode Deduktif yaitu Pola pikir diawali dari suatu proses berfikir dari ke pernyataan bersifat umum ke pernyataan yang yang bersifat khusus dengan memakai kaidah logika tertentu (Hadi Sutrisno,1998: 40). Dalam hal ini penulis berusaha memaparkan ke permasalahan yang bersifat umum tentang teori Larangan khamarperspektif pemikiran Syafi'iyah, kemudian ditarik ke teori yang bersifat khusus tentang larangan peredaran minuman Keras dalam peraturan daerah kabupaten Gresik nomor 15 tahun 2002.

\section{Hasil}

\section{Minuman keras}

a. Pengertian minuman Keras

Dalam peraturan daerah kabupaten Gresik nomor 15 tahun 2002 pada bab

1 ketentuan umum dijelaskan bahwa yang dimaksud minuman keras adalah semua jenis minuman yang beralkohol maupun tidak yang dapat membuat orang mabuk dan kecanduan.

b. Pengertian Mabuk

Mabuk adalah setiap orang yang meminum minuman keras yang berakibat berkurangnya kesadaran akibat meminum minuman keras.

2. Larangan Minuman Keras

a. Dalam Pasal 2 tentang larangan disebutkan bahwa: Dilarang bagi perorangan atau badan hukum memproduksi, mengedarkan, 
memperdagangkan, menawarkan, menimbun, menyimpan, mengoplos, menjamu, membawa dan/atau meminum minuman keras.

b. Pengecualian dari ketentuan sebagaimana dimaksud ayat (2) pasal ini adalah : Minuman beralkohol yang mengandung rempah-rempah jamu dan sejenisnya untuk tujuan kesehatan.Pasal 2 ayat (3) ini telah mengalami perubahan, sebagaimana di tunjukkan dalam dalam peraturan daerah kabupaten Gresik nomor 19 tahun 2004 tentang perubahan atas peraturan daerah kabupaten Gresik nomor 15 tahun 2002 tentang larangan peredaran minuman keras, Sebagaimana diundangkan dalam Lembaran Daerah Kabupaten Gresik Tahun 2002 Nomor 2 Seri E diubah sebagai berikut :

3. Ketentuan Pasal 2 ayat (3) berbunyi sebagai berikut :

a. Minuman beralkohol yang mengandung rempah-rempah jamu dan sejenisnya untuk tujuan kesehatan hanya disediakan di Toko obat, apotik atau toko-toko jamu(Perda Gresik No 19 tahun 2004).

b. Minuman yang disediakan oleh hotel berbintang 3, 4, 5 .

4. Ketentuan Pidana

a. Dalam Bab IV ketentuan pidana dalam pasal Pasal 8 disebutkan: Barang siapa yang memproduksi dan mengoplos minuman keras diancam dengan pidana kurungan 3 (tiga) sampai 6 (enam) bulan atau pidana denda Rp. 4.000.000,- (empat juta rupiah) sampai Rp. 6.000.000.- (enam juta rupiah)

b. Dalam Pasal 9 UU tentang ketentuan pidana disebutkan : Barang siapa mengedarkan, menawarkan dan memperdagangkan minuman keras diancam dengan pidana kurungan 2 (dua) sampai 6 (enam) bulan atau pidana denda Rp. 2.000.000,- (dua juta rupiah) sampai Rp. 6.000.000,- (enam juta rupiah). (Lembaran daerah kabupaten Gresik tahun 2002:260).

c. Dalam Pasal 12 dijelaskan hukuman pidana bagi peminum minuman keras, bahwa: Barang siapa membawa, meminum minuman keras diancam dengan pidana kurungan 1 (satu) sampai 6 (enam) bulan atau pidana denda Rp. 1.000.000,- (satu juta rupiah) sampai Rp. 3.000.000,- (tiga juta rupiah). Dijelaskan dalam peraturan daerah kabupaten Gresik nomor 19 tahun 2004 tentang perubahan atas peraturan daerah kabupaten Gresik nomor 15 tahun 2002 tentang larangan peredaran minuman keras dalam pasal I di sebutkan 
bahwa : Barang siapa membawa dan atau meminum minuman keras dapat dipidana dengan pidana kurungan paling lama 3 (tiga) bulan atau denda paling banyak Rp. 3.000.000.00 (Tiga Juta rupiah).(Lembaran daerah kabupaten Gresik tahun 2004, 214).

\section{E. Pembahasan}

\section{Larangan Khamar Perspektif Pemikiran Syafi’iyyah}

a. Minuman keras

Hakikat Khamar menurut kebanyakan Syafi'iyah adalah minuman yang memabukkan dari perasan anggur walaupun tidak dibuang busanya, adapun minuman lain yang memabukkan adalah diqiyaskan pada perasan anggur tersebut (Abdul Hamīd al-Sharwani. 2009. Jilid. 9:195). Nama Khamar digunakan untuk setiap yang memabukkan. Adapun dalil dari pada itu adalah Hadits sebagaimana diriwatkan Ibnu Umar RA. Nabi bersabda :

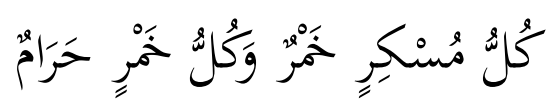

Artinya: Setiap minuman yang memabukkan itu adalah khamar dan setiap khamar haram hukumnya (Abi Dāwud, 1997, Cet. 1, juz.4-5).

Dalam mengomentari hadits diatas al-Nawawi berkata: Dalam hadits tersebut telah jelas bahwa semua minuman yang memabukkan adalah haram hukumnya dan semuanya dinamakan khamar (Al-Nawawy. 2010:448). Apabila illah (sebab hukum) keharaman khamar karena mencegah untuk ingat Allah dan shalat, maka illah ini semuanya ada pada semua minuman yang memabukkan, maka wajib disamakan hukumnya pada yang lainnya, karena minuman yang memabukkan selain khamar itu dalam satu makna. Sebagaimana firman Allah ta'ala berikut (QS, 5: 9091):

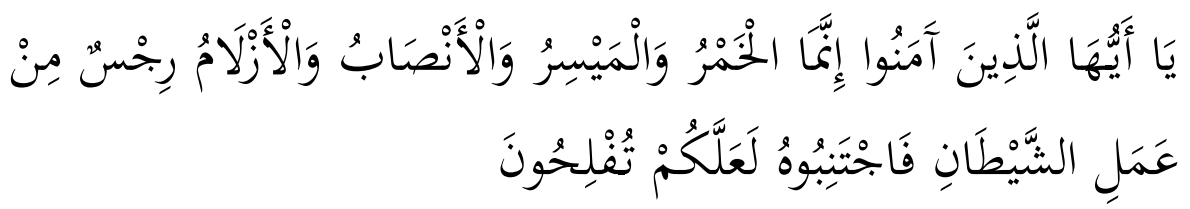




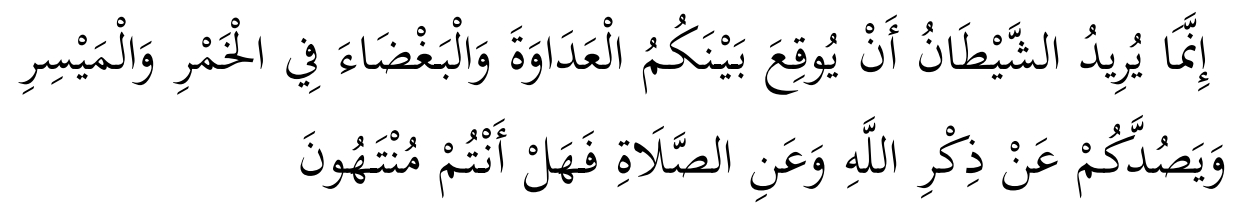

"Hai orang-orang yang beriman, sesungguhnya (meminum) khamar, berjudi, (berkorban untuk) berhala, mengundi nasib dengan panah, adalah perbuatan keji termasuk perbuatan setan. Maka jauhilah perbuatan-perbuatan itu agar kamu mendapat keberuntungan. Sesungguhnya setan itu bermaksud hendak menimbulkan permusuhan dan kebencian di antara kamu lantaran (meminum) khamar dan berjudi itu, dan menghalangi kamu dari mengingat Allah dan shalat; maka berhentilah kamu (dari mengerjakan pekerjaan itu)".

Sebagaimana hadits (Jalaluddin al- Suyuty. t.th , Juz. 8:696 dan Muslim al-Naisaburi. 2006. Cet. 1, Juz. 2:963) yang di ceritakan oleh Aisyah, Ia berkata, Nabi bersabda:

$$
\text { كُلهُ شَرَاَبْ أَنْكَرَ فَهُوَ حَرَاَهُ }
$$

Artinya : setiap minuman yang memabukkan maka haram hukumnya.

Dalam hadits yang diceritakan Jabir dari Nabi SAW. Ia berkata:

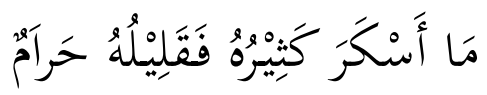

Artinya: Minuman yang banyaknya memabukkan maka minum sedikit darinya adalah haram.

Hadits ini menunjukkan bahwa keharaman pada jenis minuman memabukkan, keharamannya tidak hanya ketika mabuk, tetapi ketika tegukan pertama itu juga haram, dan wajib dikenakan hukum had pada minuman terakhir ketika di dapati Ia mabuk. Karena seluruh bagianbagiannya saling membantu dalam berbuat mabuk sama (al-Nawawi, 2010:450). Diriwayatkan dari Nu'man bin Bashir RA bahwasannya Nabi SAW bersabda :

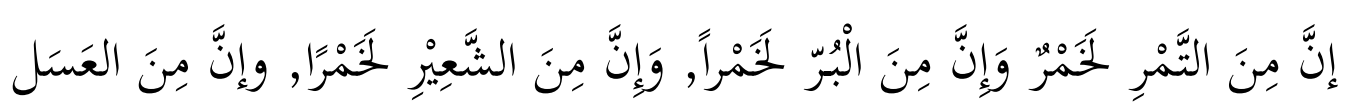

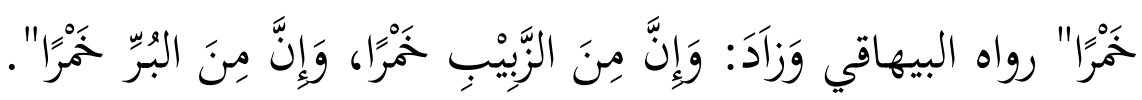

Artinya: bahwa kurma itu dapat dijadikan khamar, gandum dapat dijadikan khamar, sha'ir (jewawut) dapat dijadikan khamar, dan madu dapat dijadikan khamar. (H.R. al Baihaqy). AlBaihaqy menambahkan dalam hadits lain: "Bahwa setiap dari 
anggur dapat dijadikan khamar, setiap gandum dapat di jadikan khamar".

Dalam hadits Nu'man ini bahwa kekhususan menyebutkan al 'Inab, al Tamr, al asl, al Bur, Al Sha'ir dan al zabīb, bukan berarti bahwa khamar itu hanya terbuat dari lima macam ini, tetapi terbuat dari jenisnya yaitu berupa dharrah (bijian) dan perasan pohon, maka hukumnya hukum khamar. Adapun kekhususan menyebut lima macam ini karena kelimanya di kenal pada masa itu. Dari sini, maka semua minuman memabukkan apabila telah mengeras dan memabukkan maka hukumnya satu yaitu haram. Tidak ada perbedaan hukum dengan berbeda-beda jenisnya. Tetkala tidak halal sedikit dari khamar maka haram minum banyak maupun sedikit darinya. Apabila terjadi perbedaan nama khamar, maka tidak ada perbedaan dalam hukumnya.

Melihat konsep Khamar menurut Syafi'iyah di atas, menurut penulis minuman keras yang dimaksud dalam peraturan daerah kabupaten Gresik nomor 15 tahun 2002 pada bab 1 ketentuan umum yaitu minuman keras adalah semua jenis minuman yang beralkohol maupun tidak yang dapat membuat orang mabuk dan kecanduan, menunjukkan bahwa minuman keras tersebut tergolong khamar menurut Syafi'iyah.

Dari kata "semua jenis minuman" sebagaimana yang ada pada bab 1 ketentuan umum dapat di fahami bahwa minuman keras yang dimaksud di situ adalah jenis semua minuman keras yang tanpa memandang dan membedakan dari unsur apa minuman itu di buat, maka minuman keras di situ adalah berlaku untuk semua jenis minuman yang memabukkan tanpa membedakan apakah minuman keras tersebut dari perasan anggur maupun lainnya.

\section{Larangan Minuman Keras}

a. Larangan Khamar menurut Syafi'iyah

Menurut Syafi'iyah Haram menjual Ruṭab (kurma basah) dan anggur kepada pemeras khamar adapun dalil dari itu adalah Rasulullah SAW 
melaknat pada khamar sepuluh perkara, sebagaimana hadits yang di ceritakan oleh Umairah (Abdul Hamīd al Syarwani. 2006, juz. 4:349):

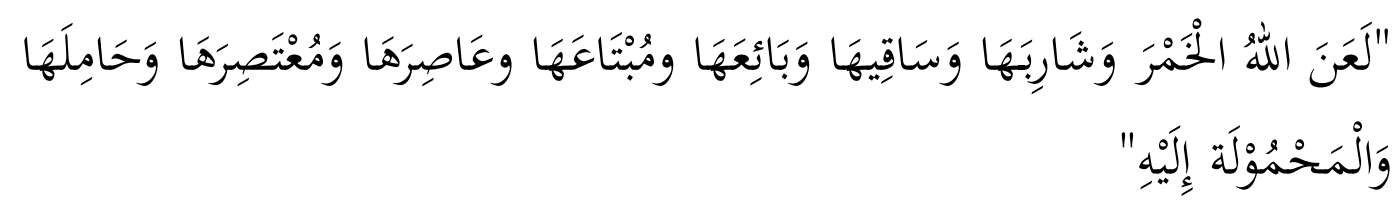

"Allah melaknat khamar, peminumnya, pemberi minum, penjualnya, pembelinya, pemerasnya, orang yang mengambil perasannya, pembawanya, orang yang di bawakan khamar dan orang yang memakan ongkos khamar"

Hadits tersebut menunjukkan atas keharaman setiap sesuatu yang menjadikan sebab maksiat dan membantu dalam kemaksiatan, diantaranya peminum khamar, pemberi minum, penjualnya, pembelinya, pemerasnya, orang yang mengambil perasannya, pembawanya, orang yang di bawakan khamar dan orang yang memakan ongkos khamar. Semua perbuatan tersebut di haramkan oleh Allah SWT karena menjadikan orang berbuat maksiat atau membantu orang dalam berbuat maksiat

Dari larangan khamar menurut Syafi'iyah sebagaimana penjelasan diatas, menurut penulis larangan dalam bab II Pasal 2 tentang larangan sebagaimana disebutkan:Dilarang bagi perorangan atau badan hukum memproduksi, mengedarkan, memperdagangkan, menawarkan, menimbun, menyimpan, mengoplos, menjamu, membawa dan/atau meminum minuman keras adalah haram yang sesuai dengan pendapat Syafi'iyah karena mengarah pada kemaksiatan atau membantu pada maksiat. Dalam pasal tersebut keharamannya berlaku mutlak atas khamar atau semua minuman keras yang memabukkan, yang mana menurut Syafi'iyah segala minuman yang memabukkan adalah khamar.

b. Berobat dengan khamar

Berobat dengan khamar menurut Syafi'iyah bahwa Khamar pada dasarnya diharamkan karena dzat khamar itu sendiri baik minum sedikit maupun banyak, dan diharamkan juga setiap minuman yang memabukkan. Hanya saja seseorang diberi kemurahan dalam meminumnya ketika dalam keadaan sangat dahaga (darurat) atau dipaksa, Ia diperbolehkan meminumnya hanya dengan kadar untuk melepaskan dari keadaan darurat tersebut, selebihnya tidak diperbolehkan (haram) (Wahbah al-Zuhaily. 104). 
Menurut Syafi'iyah juga ada keringanan dalam menghukumi berobat dengan khamar, yaitu tidak di hukum had bagi orang yang minum khamar karena untuk berobat, walaupun Ia menemukan selain khamar, Walaupun haram berobat dengan khamar tersebut. sebagaimana di nukil oleh alNawawi dan al-Rafi'i dari jama'ah (Abi Bakar al-Dimyaty. 1995. Cet. 1, Juz. 4).

Setelah melihat pendapat madzhab Syafi'iyah, menurut penulis minuman beralkohol sebagimana yang ada dalam pengecualian dalam pasal 2 ayat (3) pasal ini yaitu: Minuman beralkohol yang mengandung rempah-rempah jamu dan sejenisnya untuk tujuan kesehatan. Yang mana dalam Pasal 2 ayat (3) ini telah mengalami perubahan, sebagaimana di tunjukkan dalam peraturan daerah kabupaten Gresik nomor 19 tahun 2004 yaitu Minuman beralkohol yang mengandung rempah-rempah jamu dan sejenisnya untuk tujuan kesehatan hanya disediakan di Toko obat, apotik atau toko-toko jamu.

Pengecualian tersebut apabila sampai pada taraf kadar memabukkan maka haram hukum meminum dan memanfaatkannya untuk berobat. Karena Allah tidak menjadikan obat dari barang yang haram (khamar). Hanya saja di perbolehkan minuman beralkohol tersebut menurut Saya lebih sesuai dengan pendapat Syafi'iyah, yang mana menurut Syafi'iyah ada keringanan dalam menghukuminya, yaitu tidak di hukum had bagi orang yang minum khamar karena untuk berobat, walaupun Ia menemukan selain khamar, Walaupun haram berobat dengan khamar tersebut. sebagaimana di nukil oleh al-Nawawi dan al-Rafi'i dari jama'ah.

Melihat dari pengecualian yang kedua yaitu minuman yang disediakan oleh hotel berbintang 3, 4, 5 menurut penulis pengecualian tersebut bertentangan menurut Syari'ah, yang mana syara' tidak memperbolehkan minum minuman keras kecuali dalam keadaan dlarurat dan itupun hanya di perbolehkan hanya sebatas cukup untuk menghilangkan dlarurat sebagaimana orang boleh minum minuman keras ketika ia tersedak yang dapat menjadikan Ia dalam bahaya atau sampai mati. 
Minum minuman keras yang disediakan di hotel berbitang 3,4, dan 5 sebagaimana pengecualian dalam pasal dan ayat diatas jelas bertentangan dengan hukum syara' karena perbuatan tersebut membantu untuk menyebarkan kemaksiatan dengan mengajak orang untuk melanggar larangan Allah SWT. Madzhab Syafi'iyah melarang perbuatan tersebut. Larangan tersebut sesuai dengan hadits Nabi SAW:

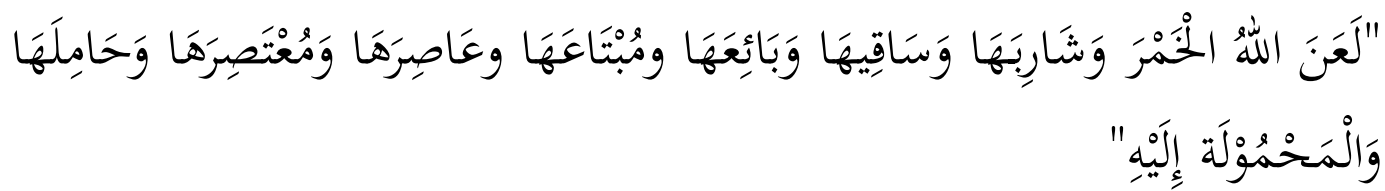

"Allah melaknat khamar, peminumnya, pemberi minum, penjualnya, pembelinya, pemerasnya, orang yang mengambil perasannya, pembawanya, orang yang di bawakan khamar dan orang yang memakan ongkos minuman keras".

Makna laknat disitu berarti menunjukkan larangan yang keras atas minuman keras (khamar) baik peminumnya, penjualnya, pembelinya, pemerasnya, orang yang mengambil perasannya, pembawanya, orang yang di bawakan khamar dan orang yang memakan ongkos minuman keras”.

\section{Hukuman Ta'zir menurut Syafi'iyah}

Menurut Syafi'iyah Ta'zir yaitu Setiap perbuatan maksiat yang tidak ada ketentuan hukuman had dan kafarahnya, maka hukumannya adalah di ta'zir dengan di penjara atau di pukul dengan telapak tangan atau di jelek-jelekkan dengan ucapan lisan, dan bagi seorang Imam berijtihad atas jenis dan kadar hukuman ta'zir (al-Syirbini. 2001:16).Dalam bab IV ketentuan pidana dalam Pasal 8 disebutkan:

"Barang siapa yang memproduksi dan mengoplos minuman keras diancam dengan pidana kurungan 3 (tiga) sampai 6 (enam) bulan atau pidana denda Rp. 4.000.000,- (empat juta rupiah) sampai Rp. 6.000.000.- (enam juta rupiah)" (Perda Gresik No 15 tahun 2002).

Dalam pasal ini beserta perubahannya sebagaimana di tunjukkan dalam peraturan daerah kabupaten Gresik nomor 19 tahun 2004 tentang perubahan atas peraturan daerah kabupaten Gresik nomor 15 tahun 2002 tentang larangan peredaran minuman keras dalam pasal I di sebutkan bahwa beberapa ketentuan pidana dalam peraturan daerah kabupaten Gresik 
nomor15 tahun 2002 tentang Larangan Peredaran Minuman Keras. Sebagaimana diundangkan dalam Lembaran Daerah Kabupaten Gresik Tahun 2002 Nomor 2 Seri E diubah sebagai berikut :

"Barang siapa yang memproduksi dan mengoplos minuman keras dapat dipidana dengan pidana kurungan paling lama 3 (tiga) bulan atau denda paling banyak Rp. 6.000.000.00 (Enam juta rupiah)" (Lembaran daerah kabupaten Gresik tahun 2004,213).

Hukuman pidana memproduksi dan mengoplos dalam pasal tersebut menurut penulis telah sesuai dengan hukum Islam perspektif Syafi'iyyah, yang mana hukuman pidana keduanya masuk dalam kategori hukuman ta'zir yang ketentuannya tergantung pada kebijaksanaan seoarang Imam, dalam hal ini adalah DPRD dengan kesepakatan dan pengesahan Bupati. Begitu juga Pasal 9 dan perubahannya sebagaimana di sebutkan:

Barang siapa mengedarkan, menawarkan dan memperdagangkan minuman keras diancam dengan pidana kurungan 2 (dua) sampai 6 (enam) bulan atau pidana denda Rp. 2.000.000,- (dua juta rupiah) sampai Rp. 6.000.000,- (enam juta rupiah).

Dalam pasal ini juga terdapat perubahan sebagaimana di tunjukkan dalam peraturan daerah kabupaten Gresik nomor 19 tahun 2004 tentang perubahan atas peraturan daerah kabupaten Gresik nomor 15 tahun 2002 tentang larangan peredaran minuman keras dalam pasal I disebutkan bahwa beberapa ketentuan pidana dalam peraturan daerah kabupaten Gresik nomor15 tahun 2002 tentang Larangan Peredaran Minuman Keras. Sebagaimana diundangkan dalam Lembaran Daerah Kabupaten Gresik Tahun 2002 Nomor 2 Seri E diubah sebagai berikut :

Barang siapa mengedarkan, menawarkan dan memperdagangkan minuman keras dapat dipidana dengan pidana kurungan paling lama 3 (tiga) bulan atau denda paling hanyak Rp. 6.000.000.00 (Enam Juta Rupiah).

Pasal ini menurut penulis sama dengan pasal sebelunya dalam hukumnya, yaitu Setiap perbuatan maksiat yang tidak ada ketentuan hukuman had dan kafarahnya maka hukumannya adalah di ta'zir dengan di penjara atau di pukul dengan telapak tangan atau di jelek-jelekkan dengan ucapan lisan, dan bagi seorang Imam berijtihad atas jenis dan kadar hukuman ta'zir. 
Adapun wujud dari ijtihad seorang Imam atau pemimpin ialah ketentuan sebagaimana yang diatur dalam pasal ini. Yaitu seseorang yang diketahui mengedarkan, menawarkan dan memperdagangkan minuman keras dapat dipidana dengan pidana kurungan paling lama 3 (tiga) bulan atau denda paling hanyak Rp. 6.000.000.00 (Enam Juta Rupiah).

\section{Hukum Pidana Bagi Peminum Khamar}

a. Hukum had menurut Syafi'iyah

Adapun hukum bagi peminum minuman keras menurut Syafi'iyah adalah empat puluh pukulan cambuk bagi orang merdeka dan dua puluh cambukan bagi seorang budak. Diperbolehkan bagi seorang Imam menjadikan cambukan menjadi delapan puluh pukulan atas orang merdeka dan empat puluh atas budak, dan kelebihan dari had tersebut dianggap Ta'zir (Muhammad al-Shatirī. 2007:716).

Apabila seseorang meminum minuman keras yang dapat menyebabkan hilangnya akal maka dia wajib di hukum cambuk atau dera. Begitu juga apabila meminum minuman keras banyak memabukkan maka meminum sedikitpun dari minuman tersebut haram dan wajib baginya hukum had menurut Syafi'iyah. Adapun dalil yang di gunakan oleh Imam Syafii atas hukuman dera atau cambuk empat puluh kali adalah sebagaimana yang telah dilakukan oleh Nabi SAW, perbuatan Nabi SAW adalah Hujjah yang tidak boleh di tinggalkan dengan mengikuti melakukan selain seperti Nabi SAW. Sedangkan hukuman cambuk lebih dari empat puluh itu adalah dari Umar bin Khattab RA yaitu berupa ta'zir jadi boleh bagi Imam melakukan cambuk lebih dari empat puluh sebagaimana yang dilakukan oleh Umar bin Khattab.

Apabila seorang Imam melakukan hukum jilid 40 cambukan dan yang dihukum mati maka seorang Imam tidak menanggung atas kematiannya, karena hak itu matinya dia. Sedang apabila seorang Imam menghukumnya dengan 80 jilid pukulan dan mati, maka separuh diyāt kematiannya di tanggung Imam karena separuhnya had dan separuhnya adalah ta'zīr, sehingga gugur separuh karena had dan wajib separuh sebab ta'zīr (al- 
Nawawi. 2010:445). Dalam Pasal 12 dijelaskan hukuman pidana bagi peminum minuman keras, bahwa:

Barang siapa membawa, meminum minuman keras diancam dengan pidana kurungan 1 (satu) sampai 6 (enam) bulan atau pidana denda Rp. 1.000.000,- (satu juta rupiah) sampai Rp. 3.000.000,- (tiga juta rupiah) (Lembaran daerah kabupaten Gresik tahun 2002:261).

Dalam pasal ini terdapat perubahan sebagaimana di tunjukkan dalam dalam peraturan daerah kabupaten Gresik nomor 19 tahun 2004 tentang perubahan atas peraturan daerah kabupaten Gresik nomor 15 tahun 2002 tentang larangan peredaran minuman keras dalam pasal I di sebutkan bahwa beberapa ketentuan pidana dalam peraturan daerah kabupaten Gresik nomor15 tahun 2002 tentang Larangan Peredaran Minuman Keras. Sebagaimana diundangkan dalam Lembaran Daerah Kabupaten Gresik Tahun 2002 Nomor 2 Seri E diubah sebagai berikut :

Barang siapa membawa dan atau meminum minuman keras dapat dipidana dengan pidana kurungan paling lama 3 (tiga) bulan atau denda paling banyak Rp. 3.000.000.00 (Tiga Juta rupiah).

Pasal ini menurut penulis tidak sesuai dengan hukum Islam menurut perspektif pemikiran Syafi'iyah karena hukuman bagi orang yang meminum-minuman keras telah ada ketentuan hukumannya berupa had sehingga ketika ada hukum hadnya maka tidak boleh beralih kepada hukum ta'zir sebagaimana yang ada dalam pasal ini.

\section{F. Kesimpulan}

Hasil dari penelitian ini sebagaimana telah diuraikan, maka dapat diambil kesimpulan bahwa Larangan peredaran minuman keras sebagaimana yang di maksud dalam peraturan daerah kabupaten Gresik nomor 15 tahun 2002 termasuk kategori larangan khamar menurut perspektif pemikiran Syafi'iyah. Dasarnya diambilkan dari hadits Nabi SAW.

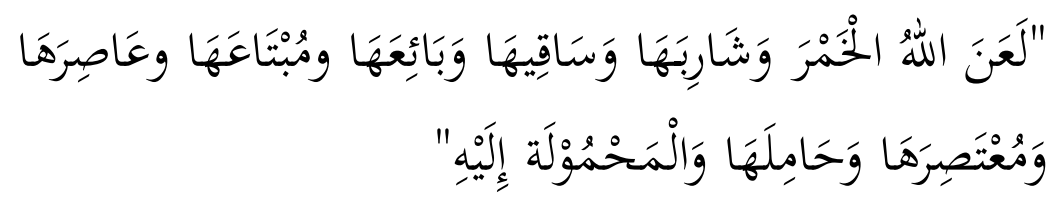


"Allah melaknat khamar, peminumnya, pemberi minum, penjualnya, pembelinya, pemerasnya, orang yang mengambil perasannya, pembawanya, orang yang di bawakan khamar dan orang yang memakan ongkos minuman keras".

Minuman keras dalam peraturan daerah kabupaten Gresik tersebut sesuai dengan pendapat Syafi'īyah.Sedangkan ketentuan pidana selain meminum minuman keras sebagimana di jelaskan dalam pasal Pasal 8, 9. Ketentuan hukum tersebut menunjukkan kesesuaian dengan hukum Islam yang dalam hal ini menurut Syafi'iyah bahwa ketentuan hukuman pidana ini masuk dalam kategori hukum Ta'zir yaitu Setiap perbuatan maksiat yang tidak ada ketentuan hukuman had dan kafarahnya, maka hukumannya adalah di ta'zir dengan di penjara atau di pukul dengan telapak tangan atau di jelek-jelekkan dengan ucapan lisan, dan bagi seorang Imam berijtihad atas jenis dan kadar hukuman ta'zir. Sedangkan ketentuan pidana bagi peminum minuman keras sebagaimana disebutkan dalam Pasal 12 diancam dengan pidana kurungan paling lama 3 bulan atau pidana denda paling banyak empat juta rupiah. Hukuman pidana dalam Pasal tersebut tidak sesuai dengan hukum Islam menurut perspektif pemikiran Syafi'iyah karena hukuman bagi orang yang meminum-minuman keras telah ada ketentuan hukumannya berupa had sehingga ketika ada hukum hadnya maka tidak boleh beralih kepada hukum ta'zir sebagaimana yang ada dalam pasal ini. Jadi secara umum Larangan peredaran minuman keras dalam peraturan daerah kabupaten Gresik Nomor 15 Tahun 2002 termasuk kategori hukum Islam berupa Larangan khamar perspektif pemikiran Syafi'iyah walaupun ada sebagian pasal tentang ketentuan pidana yang tidak sesuai dengan hukum Islam.

\section{Daftar Pustaka}

Al Qur'an dan Terjemahnya Departemen Agama RI. 1989.

Abdurrahman, bin Abi Bakr. 2008. Lubab An Nuqul Fi Asbab An Nuzul (Mișr: Dōr al- Muqattam).

Anshari (Al) Zakariyyah Muhammad, Muqaddimah min Ghayat al Wusul, Hadramaut: Dōr al-Dhahabī, tt.

Aj̄urjanī (Al), Ali b. Muhammad. 2003. Kitab al-Ta'rifah, Bairut: Dōr Ihya' Turath al Arabī.

Dōwud Abi.1997. Sunan Abi Dōwud. Beirut: Dōr al-Hazm

Dimyaty (Al) Abi Bakar. 1995. İ̄̄nah al- Țālibīn. Beirut: Dōr al-Kutub al-Ilmiyah 
http://www.jdih-Gresik.net/index.php?pilih=download\&mod=yes, peraturan daerah kabupaten Gresik nomor 15 tahun 2002 tentang larangan peredaran minuman keras. Diakses 5 Januari 2018

Lembaran daerah kabupaten Gresik tahun 2004. “ peraturan daerah kabupaten Gresik nomor 19 tahun 2004 tentang perubahan atas dalam http://www.jdih.setjen.kemendagri.go.id/files/KAB_GRESIK_19_2004 .pdf.. Diakses 5 Januari 2018

Nawawy (al), muhyiddin. 2010. al-Majmu’. Libnan: Dōr al-Fikr

Naisaburi (al),Muslim. 2006. Shoheh Muslim. Riyaḍ: Dōr Thoyibah.

Nasir, Muhammad. 1985. Metode Penelitian. Jakarta: Ghalia Indonesia.

Sharwani (Al), Abdul Hamīd. 2009. Hawashī. Beirūt: Dōr al-Fikr.

Sayraji (Al), Ibrahim. 1994. Al Muhaddab. Bairut:Dar Alfikr.

Shatirī (Al), Muhammad b. Ahmad. 2007. Sharh Yaqut An Nafis Fi Madab Ibnu Idris. Jeddah: Dōr al-Minhaj,.

Shirbin̄̄ (al), Muhammad. 2001. Mughni Muhtaj. Bairut: Dōr Ihya' al Turats al Arabi.

Suyuty (Al), Jalaluddin, Sunan an-Nasa 'i. Beirut:Dōr al -Ma'rifah, t.th.

Sutrisno, Hadi. 1998. Metodologi Research. Yogyakarta:Fak. Sosiologi UGM.

Zuhaily (al), Wahbah. 2008. al Fiqh al Islam Wōdillatuh. Damaskus: Dōr al-Fikr. 